\title{
The Level of Livelihood Assets Ownership Among Vulnerability Group in East Coast of Malaysia
}

\author{
Ahmad Zubir Ibrahim ${ }^{1}$, Kalthum Hj Hassan ${ }^{1}$, Roslina Kamaruddin ${ }^{2}$, \\ Abd Rahim Anuar ${ }^{3}$
}

\begin{abstract}
This paper aim to analyze the level of livelihood assets ownership among vulnerability group in Kelantan, East Coast of Malaysia. A total of 300 respondents comprising the vulnerability group in the rural area, State of Kelantan has been chosen to achieve this goal. Based on Sustainability Livelihood Analysis, a structured questionnaires has been develop to collect information on the livelihood assets, which consist of human, financial, social, natural and physical assets. This study found that the human asset is the key asset which contributes to the livelihood compared to other assets of the vulneralbility group in Kelantan. This study will benefit the policy makers, which directly involved with the development of rural communities. This study also proposes a number of remedies that need to be addressed in order to improve the sustainability of livelihoods among vulnerability group.
\end{abstract}

Keyword: sustainability, vulneralbility group, livelibood assets

\section{Introduction}

The sustainable livelihoods idea was first introduced by the Brundtland Commission on Environment and Development, and the 1992 United Nations Conference on Environment and Development expanded the concept, advocating for the achievement of sustainable livelihoods as a broad goal for poverty eradication [1]. In 1992 Robert Chambers and Gordon Conway proposed the following composite definition of a sustainable rural livelihood, which is applied most commonly at the household level namely, a livelihood comprises the capabilities, assets (stores, resources, claims and access) and activities required for a means of living: a livelihood is sustainable which can cope with and recover from stress and shocks, maintain or enhance its capabilities and assets, and provide sustainable livelihood opportunities for the next generation; and which contributes net benefits to other livelihoods at the local and global levels and in the short and long term.

Of the various components of a livelihood, the most complex is the portfolio of assets out of which people construct their living, which includes both tangible assets and resources, and intangible assets such as claims and access. There are five different types of assets own by individual to build their livelihoods which consists of natural, social, human, physical and financial assets. Livelihood assets ownership was related to achieve sustainability livelihood. Based on this statement, government intervention more focus and emphasize for this purpose. In Malaysia, government has implemented various

\footnotetext{
| 1 School of Government, Universiti Utara Malaysia

${ }^{2}$ School of Economic, Finance and Banking, Universiti Utara Malaysia

${ }^{3}$ School of International Affair, Universiti Utara Malaysia
} 
policies such as Rancangan Malysia Lima Tabun (RMLT), Government Transformation Planning, and Economic Transformation Planning and so on to increase level of income households. This is very important to ensure the households especially in the poor group bracket will achieve sustainability livelihood. Therefore understanding the livelihood assets among poor group is very important for the implementation of development plans in future. This paper aim to analyze the level of livelihood assets possession among poor in Kelantan, Malaysia. Kelantan which register one of the highest poverty incidence in Malaysia [2]. This study also calculate the sustainability livelihood index to further explaining the analysis of these assets.

\section{Materials and Methods}

This study is confined to Kelantan which situated in East Coast of Northern Malaysia which ranked second in terms of poverty rate. There are 300 respondents among vulnerability group (paddy farmers, coastal fisherman and rubber tapper) involve this study. Data was collected using a structured questionnaires which was designed based on Sustainable Livelihood Analysis (SLA) frame work. Data analysis consists of the descriptive statistic of livelihood assets to get a better understanding of the ownership livelihood assets among vulnerability group or poor group. To compare the ownership between five livelihood assets, this study using sustainability livelihood index [3].

Index $_{s d}=\frac{S_{d}-S_{\min }}{S_{\max }-S_{\min }}$

Where, $\mathrm{S}_{\mathrm{d}}$ was the original sub-component for community $d$, and $S_{\min }$ and $S_{\max }$ were the minimum and maximum values, respectively, for each sub-component determined using data from the same community surveyed. The household percentiles determined as 0 at minimum level and 1 at maximum level.

\section{Results}

\subsection{Ownership of Livelihood Assets}

Human assets: Department for International Development [4] assumes human assets as a combination of capabilities, skills and knowledge, and material health which enable households and individuals to make livelihoods and attain secure livelihood outcome [5]. Human asset entails a combination of abilities that endow the individual or households or individual towards earning livelihoods accomplishment. Based on this study, it show 10.3 percent of those who never attended school among the vulnerability group and 16 percent respondents have successfully completed secondary school education. A total of 36.7 percent respondents has received education at primary school level only. The study found that respondents vulneralbility group have health problems which accounted a high percentage of 30 percent. Most of the health problems encountered among the respondents are diabetes, hypertension and heart problem. The outcome of the survey showed most of the respondents were found to be never attended a lecture or talks on health issues. The percentage of respondents who attend this lecture shows the percentage does not even reach 50 percent out of total respondents. Only 17 
percent of respondent attended the training and knowledge program organized.

Financial Assets: Lasse emphasize financial assets denotes the financial resources that people use to achieve livelihood objectives [1]. The definition applied here is not economically robust. In this definition, it includes flows as well as stocks, and it can contribute to consumption as well as production. This study find out average income per month among respondent RM1227.93 (USD306) and income expenditure RM 910.94 (USD227) per month. Overall respondents received subsidies from the government. Various types of interventions by government have been implemented to help the less fortunate to improve their living standards. Among the subsidies granted is in the form of fertilizer subsidy, equipment/ mechanization, intensives for replanting and so on. This study also found that around 31.3 percent of respondents do have savings.

Physical assets: Physical assets means the required accessibilities facilities needed by households or individuals like transportation good facility, good housing, safe drinking water, and accessibility to medical facilities, market and schools [6]. In this study, the distance between the residences to the city also affects the ability of the people in rural areas to obtain the services provided. Findings from the survey found the average distance between the respondent's house to the city is within a $3.23 \mathrm{~km}$. However, 18 percent among respondents have more than $5 \mathrm{~km}$ distance from their house to the city. The distance to the city very important to evaluate so that the vulneralbility group not facing the food dessert problem. From this study also find out overall the respondent has at least a motorcycle. This type of vehicle ownership percentage exceeds more than 90 percent. In terms of car ownership, study show 52.3 percent respondent have a car. On the other hand, ownership of household goods in terms of media entertainment and information, most of the respondents has a television (97 percent) and 78.3 percent own a radio.

Natural capital: Goldman point out natural capital is the term used for natural resource stocks from which resource flow and services (e.g., nutrient cycling and erosion protection) that are useful for livelihoods are derived. Natural capital is constituted by a wide variation in resources from intangible public goods such as the atmosphere and biodiversity to divisible assets used directly in the production of goods (such as trees, land) [7]. In this study 23 percent respondents was taken protein from fishing, 29.7 percent gardening practices and 21.7 percent use environment resources as a food sources.

Social assets: To increase individual's capability, social asset also represents social resources which provide prospects to the vulnerable households through social relations and interactions like bonds, bridges and linkage which bring equal mutual benefit to both parties in the social relations [8]. This study find out 44.7 percent respondents involve in society either political parties or non-governmental organization. In community level, only 52 percent respondent involve in community activity.

Index of livelihood assets: Index of the livelihood assets was ascertained based on selected indicator as shown in Table 1. General scores were calculated by means of a Composite Index on the basis of the standardized process of the above data. Results are shown in the following (Figure 1). Of the five livelihood capitals, human assets possessed the highest value (0.65) and social assets possessed a moderate high value (0.516) followed by natural assets (0.46). This represents how human assets such as 
education, experience, skill, knowledge would affect production and lifestyle in order to improve the livelihood among vulnerability group in Kelantan, East Coast of Northern Malaysia. Financial assets and physical assets ownership register relatively low values (0.33 and 0.4 respectively). Of the five livelihood assets, financial assets provided the most significant influence. The lack of financial assets would inhibit this group to increase production scales and develop infrastructures that would, consequently, make it difficult to achieve livelihood diversification. Lending policies to this group should produce a certain offset by improving environmental investments, strengthening the effect of cooperative organizations and associations, and improving the overall financial assets ownership of this group. This would enable and motivate in the improvement of other assets, thereby contributing to the general improvement of the livelihood level of vulnerability group [9].

Table 1: List of indicators for livelihood assets

\begin{tabular}{|c|c|c|c|c|}
\hline Human Assets & Financial Assets & Natural Asset & Social Assets & \begin{tabular}{|l|} 
Physical \\
assets
\end{tabular} \\
\hline $\begin{array}{l}\text { Highest level of } \\
\text { education Head of } \\
\text { Household }\end{array}$ & $\begin{array}{l}\text { Household } \\
\text { income }\end{array}$ & Ownership of land & $\begin{array}{l}\text { Position in society } \\
\text { or organization }\end{array}$ & Water sources \\
\hline Working experience & $\begin{array}{l}\text { Income from non- } \\
\text { economic } \\
\text { activities }\end{array}$ & $\begin{array}{l}\text { Ownership } \\
\text { livestock }\end{array}$ & $\begin{array}{l}\text { Involvement in } \\
\text { community activity }\end{array}$ & $\begin{array}{l}\text { Housing } \\
\text { characteristic }\end{array}$ \\
\hline Knowledge level & Subsidies recipient & $\begin{array}{l}\text { Food resources } \\
\text { from environment }\end{array}$ & $\begin{array}{l}\text { Involvement in } \\
\text { political party }\end{array}$ & $\begin{array}{l}\text { Distance to } \\
\text { town }\end{array}$ \\
\hline Training attend & Saving amount & & $\begin{array}{l}\text { Involvement in } \\
\text { agriculture society }\end{array}$ & $\begin{array}{l}\text { Vehicle } \\
\text { ownership }\end{array}$ \\
\hline
\end{tabular}

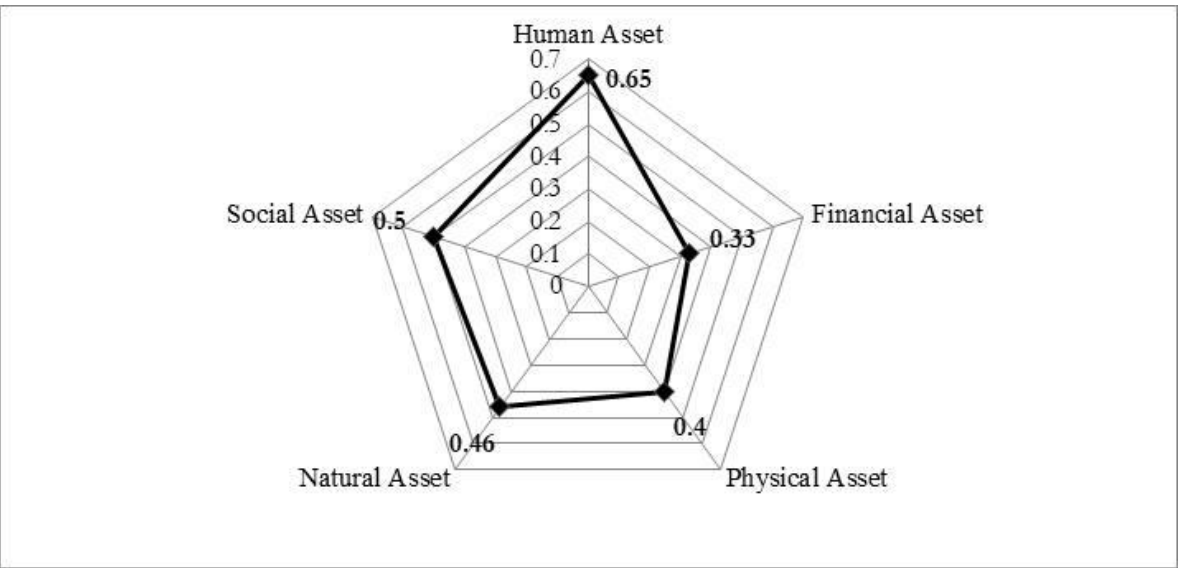

Figure 1: Livelihood assets spider diagram for vulnerability group in Kelantan, Malaysia

\section{Conclusion}

Understanding the current situation especially livelihood assets among vulnerability group or poor group is very important for government to implement the 
best practice to assist this group. Different livelihood activities have different requirements, but a general principle must be established among this vulnerability group, who are amply endowed with assets are more likely to make positive livelihood choices. They can choose from a range of options in order to maximize the achievements obtained from positive livelihood outcomes rather than being forced into a given strategy due to being the sole option available [9].

Based on this study it shows that, to increase better lifestyle among this group, warrants accessibility to quality education and skills training for the next generation this group will enhance for a healthier future. At the same time, head of households who are selfemployed such farmers, fisherman and smallholder will be encouraged to adopt modern technology to increase productivity and income. Structured modular program focusing on modern farming techniques and good agricultural practiced need to intensify. To increase financial assets, rural entrepreneurship need to be encouraged among this group. The entrepreneurial orientation program will focus on stimulating local entrepreneurial talent and growth of indigenous companies [10]. Governmental institutions also should actively adopt effective means of financial support in order to prompt farmers to abandon agricultural production and engage in non-agricultural enterprises, thereby achieving an industry-oriented lifestyle [9].

\section{Acknowlegments}

This study was supported by Ministry of Higher Education of Malaysia and Universiti Utara Malaysia (Granted FRGS. SO Code: 13249),

\section{References}

[1] Lasse K, (2001). The Sustainable Livelihood Approach to Poverty Reduction. International Development Cooperation Agency, Sweden. http://www. forestry.umn.edu/prod /groups/cfans/@pub/@cfans/@ forestry/documents/asset/cfans_asset_202603.pdf.

[2] Malaysia (2017) Household Income \& Poverty http://www.epu.gov.my/en/socio-economic/householdincome-poverty

[3] Hahn, MB, Riederer, AM, Foster, SO (2009) The livelihood vulnerability index: A pragmatic approach to assessing risks from climate variability and change-A case study in Mozambique. Global Environmental Change 19(1): 74-88.

[4] Department for International Development. (2001). Sustainable livelihoods guidance sheets. www.livelihoods.org/info/info_guidanceSheets.html\#6: DFID.

[5] Krantz, L. (2001). The sustainable livelihood approach to poverty reduction, SIDA. Division for policy and socio-economic analysis. Retrieved from- http://www.forestry.umn.edu /prod/groups/cfans/@pub/@cfans/@forestry/documents/asset/cfans_asset_202603.pdf

[6] Samsudin, S., \& Kamaruddin, R. (2013). Distribution of the livelihood asset among the hardcore poor: Evidence from Kedah, Malaysia. World Applied Science Journal, 28, 38-42. DOI: 10.5829/idosi.wasj.2013.28.efmo.27008

[7] Goldman I, (2000). Sustainable Livelihoods Approaches: Progress and Possibilityes for Change. http://www.eldis.org/vfile/upload/1/document/0812/ SLA_Progress.pdf.

[8] Coleman, J. S. (1988). Social capital in the creation of human capital. American Journal of Sociology, 9, 95120. http://doi.org/10.1086/228943.

[9] Su. F, \& Shang, H.Y. (2012). Relationship analysis between livelihood assets and livelihood strategies: A Heihe River asin example, Sciences in Cold and Arid Regions, 4(3): 0265-0274

[10] Malaysia (2011). 11th Malaysian Plan. Economic Planning Unit, Prime Minister's Department. Putrajaya: Prime Minister's Department 